nature and management of schizophrenia, proved an irresistible draw.

So that's it - a mixture of patient care, management, research and College matters make up my psychiatric day. I greatly enjoy my job. I count myself lucky.

\section{References}

Blackwood, D. H. R., Muir, W. J., St Clair, D. M. \& WALKER, M. T. (1990) Genetic trait makers in schizophrenic probands and their unaffected relatives. In: International Perspectives in Schizophrenia (ed. M. Weller). London: John Libbey.
LADER, M.\& HeRrIngton, R. (1990) Biological Treatments in Psychiatry. Oxford: Oxford Medical Publications.

McCreadie, R. G., Stewart, M., Robertson, I. \& Dingwall, J. M. (1991) The Scottish survey of old long stay in-patients. British Journal of Psychiatry, In press.

Maclennan, D. Gibb, K. \& More, A. (1990) Paying for Britain's Housing. York: Joseph Rowntree Foundation.

SCottish Home and Health Department (1989) Mental Hospitals in Focus. Report by a Working Group of NMCC on the Future Role of Mental Illness Hospitals in Scotland. Edinburgh: HMSO.

SCOTtISH Schizophrenia Research Group (1987) The Scottish first episode schizophrenia study. British Journal of Psychiatry, 150, 331-344.

\title{
Asylum History
}

\section{Buckinghamshire County Pauper Lunatic Asylum - St John's}

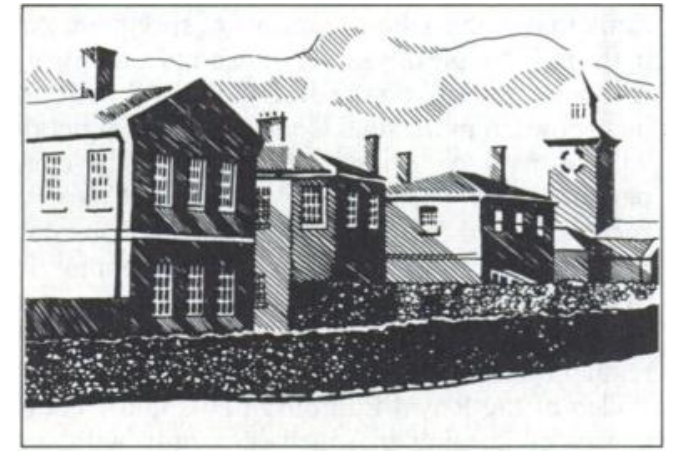

GASKELL
By John Crammer

f10, 196pp., ISBN 0902241346

Why were asylums built, who were the mad put in them, how were they treated there, and what became of them? What happened in Buckinghamshire over 18501980 is set against the social history of the times. This book is a timely reminder of the evolution of mental health services, and provides a vital background to hospital closure.

Royal College of Psychiatrists 